\title{
Harvesting Environmental Microalgal Blooms for Remediation and Resource Recovery: A Laboratory Scale Investigation with Economic and Microbial Community Impact Assessment
}

\author{
Jagroop Pandhal ${ }^{1, *}$, Wai L. Choon ${ }^{1}$, Rahul V. Kapoore ${ }^{1}$ (D), David A. Russo ${ }^{2}$ (D), James Hanotu ${ }^{1}$, \\ I. A. Grant Wilson ${ }^{1}$, Pratik Desai ${ }^{1}$ (i), Malcolm Bailey ${ }^{3}$, William J. Zimmerman ${ }^{1}$ and \\ Andrew S. Ferguson ${ }^{1}$ \\ 1 Department of Chemical and Biological Engineering, The University of Sheffield, Sheffield S1 3JD, UK; \\ liong_waichoon91@hotmail.com (W.L.C.); r.kapoore@sheffield.ac.uk (R.V.K.); j.hanotu@sheffield.ac.uk (J.H.); \\ grant.wilson@sheffield.ac.uk (I.A.G.W.); p.desai@sheffield.ac.uk (P.D.); \\ w.zimmerman@sheffield.ac.uk (W.J.Z.); andrew.ferguson@sheffield.ac.uk (A.S.F.) \\ 2 Copenhagen Plant Science Centre, Department of Plant and Environmental Sciences, \\ University of Copenhagen, Thorvaldsensvej 40, C 1871 Frederiksberg, Denmark; russo@plen.ku.dk \\ 3 Link2Energy, 1-3 Bigby Street, Brigg, North Lincolnshire DN20 8EJ, UK; malcolm@link2energy.co.uk \\ * Correspondence: j.pandhal@sheffield.ac.uk; Tel.: +44-(0)114-222-4914
}

Received: 20 November 2017; Accepted: 23 December 2017; Published: 29 December 2017

\begin{abstract}
A laboratory based microflotation rig termed efficient FLOtation of Algae Technology (eFLOAT) was used to optimise parameters for harvesting microalgal biomass from eutrophic water systems. This was performed for the dual objectives of remediation (nutrient removal) and resource recovery. Preliminary experiments demonstrated that chitosan was more efficient than alum for flocculation of biomass and the presence of bacteria could play a positive role and reduce flocculant application rates under the natural conditions tested. Maximum biomass removal from a hyper-eutrophic water retention pond sample was achieved with $5 \mathrm{mg} \cdot \mathrm{L}^{-1}$ chitosan ( $90 \%$ Chlorophyll $a$ removal). Harvesting at maximum rates showed that after 10 days, the bacterial diversity is significantly increased with reduced cyanobacteria, indicating improved ecosystem functioning. The resource potential within the biomass was characterized by $9.02 \mu \mathrm{g}$ phosphate, $0.36 \mathrm{mg}$ protein, and $103.7 \mu \mathrm{g}$ lipid per mg of biomass. Fatty acid methyl ester composition was comparable to pure cultures of microalgae, dominated by C16 and C18 chain lengths with saturated, monounsaturated, and polyunsaturated fatty acids. Finally, the laboratory data was translated into a full-size and modular eFLOAT system, with estimated costs as a novel eco-technology for efficient algal bloom harvesting.
\end{abstract}

Keywords: environmental microalgae; resource recovery; eutrophication; microflotation; algal bloom

\section{Introduction}

The world's growing population is putting pressure on natural resources and increasing waste production. Current rates and practices will deplete finite resources whilst potentially causing irreversible pollution to natural ecosystems. Nutrient release (e.g., nitrogen $(\mathrm{N})$ and phosphorus $(\mathrm{P})$ ) is a major source of anthropogenic pollution. Sources of these nutrients include fertilizers, sewage and industrial effluents [1]. Most of these nutrients accumulate within aquatic ecosystems, leading to eutrophication of static water bodies including lakes and reservoirs. Indeed, $30-40 \%$ of global lakes and reservoirs are now classified as eutrophic, leading to algal blooms [2] that can be toxic, reduce biodiversity, damage ecosystem health, and kill wildlife. Moreover, climate change is expected to 
heighten the problem [3]. "Mega-algal blooms" have been recorded in the USA, where the economic cost has been estimated at $\$ 2.2$ billion per year $[4,5]$, and a single bloom event in Lake Taihu was estimated to have cost the Chinese economy $\$ 6.5$ billion [6].

Efforts to remediate eutrophic water systems are varied and limited in success. Reducing external nutrient loading is the preferred option. This system relies on identifying a point source, or if the problem is diffuse pollution (e.g., from agriculture or urban areas), the task becomes more complex. Options to reduce diffuse pollution include catchment scale management driven by policy [7]. As well as involving local stakeholders, a major concept is 'slow water', i.e., slowing flow of water from land into watercourses through the use of constructed wetlands or 'buffer strips'. Even if reduced external loading is achieved, $\mathrm{P}$ can be released from sediments (legacy $\mathrm{P}$ ) for many years [8]. Biomanipulation is difficult to control and predict due to the instability of aquatic communities and the fundamental problem remains that the nutrient is not removed. In some countries, notably the USA, nutrients are locked in the sediment using chemicals, but similar issues with long-term P release from sediment occur [9]. There have also been recent efforts to install filamentous algal-based scrubbing systems to remove nutrients from agricultural storm water [10]. An alternative option is to harvest the environmental algal biomass, thus removing a proportion of the nutrients that reside within algal cells to help break the continual eutrophication loop caused by internal nutrient loading or diffuse pollution. Although algal harvesting should be considered as an addition to the lake restoration toolbox, the associated energy costs can be prohibitive. As experienced by the algal biodiesel community, up to $30 \%$ of the overall process costs can be attributed to harvesting microalgal cells [11]. Accordingly, sedimentation and flotation are generally considered the most viable low-cost harvesting methods for large volumes of microalgal biomass. In regards to flotation, dissolved air flotation (DAF) is a well-established process for separating suspended particles from the liquid phase, by bringing the particles to the surface [12]. Microbubbles are formed when water, saturated with air at high pressure, is released from a diffuser. These then attach to flocculated particles rising to the surface [12]. This process is applied across many industries e.g., domestic wastewater treatment, oil refineries, and metal ore processing. However, these industries work within closed systems, where conditions can be manipulated to optimize harvesting efficiencies. Moreover, due to DAF requiring high-pressure nozzles, or more recently methods such as ultrasound [13], energy costs are relatively high, making the application to large amounts of water, such as a eutrophic lake or retention pond, prohibitive. Indeed, wastewater aeration using microbubbles has been estimated to consume up to $0.4 \%$ of the UK's total energy consumption [14].

Recently, a device termed a fluidic oscillator (FO) that exploits microfluidic principles by converting laminar air flow into oscillatory flow, followed by ejection of microbubbles through a diffuser, has shown considerable promise for widening the applications of microbubbles [15]. Bubble production has been demonstrated at a large-scale (2200 L) in a continuous state operation (tested to 17 days) [16]. With no requirement for pressurization and liquid pumping, the process only uses a fraction of the energy of traditional DAF methods [17]. Microflotation using the FO has been applied to harvest pure cultures of yeast and dead microalgal cells $[16,18]$ but has not been applied to environmental samples with live microalgae and bacterial consortia. Therefore, we incorporated the FO into the design of a laboratory-scale environmental algae harvesting device, termed efficient FLOtation of Algae Technology (eFLOAT) (Supplementary Figure S1).

This study seeks to examine the potential of eFLOAT to harvest environmental biomass from a bloom event, conducted under the constraint of near-natural environmental conditions. Through a series of laboratory-based experiments, data were generated for a proof of concept for the flocculation and subsequent removal of algal blooms (and nutrients) from lakes. Preliminary sedimentation trials aimed to compare flocculation efficiencies to (1) compare an environmentally sourced lake sample with pure microalgae cultures to assess for differences in flocculant doses; (2) compare a common chemical flocculant (aluminium sulphate or alum) with a biopolymer flocculant (chitosan), where the former has been associated with risks to aquatic life 
and is known to impact on the downstream use of recovered algal biomass; and (3) gain insight into the effects of having more bacteria present. Subsequently, a sedimentation test was undertaken using P-rich water sourced from a water retention pond (WRP), owned by a UK water company and known to experience regular algal blooms. This was performed to select two conditions for maximum and sub-maximum harvesting of microalgae using eFLOAT. The eFLOAT experiment was undertaken and P-removal rates were calculated. In terms of an environmental remediation technique, Chlorophyll $a$ (Chl $a$ ) levels were compared pre- and post-harvesting after a prolonged period (10 days), using a non-harvested sample as a control. The bacterial and eukaryotic diversity was also characterized within these samples, as an increase in microbial diversity was considered an indication of improved ecosystem function and, therefore, health [19].

Although environmental remediation is the main focus of eFLOAT, the advantages can be further improved if the biomass can be used as a resource. Recently, microalgae have attracted significant interest globally as a potential feedstock for the bio-based economy [20]. Here, we characterize and quantify three biochemical constituents (lipids, phosphates and proteins) in the recovered biomass, which represent different potential resource streams including precursors for industrial chemicals, fuels, fertilizers, and protein feed. The focus here is microalgae and not potentially toxic cyanobacterial blooms. Finally, it is of interest to consider the requirements of a full size eFLOAT modular device. Therefore, an operating and capital expenditure was undertaken based on the findings of the laboratory experiments and data within the literature, incorporating a solar-powered eFLOAT system.

\section{Materials and Methods}

\subsection{Sample Collection}

Environmental samples were collected using a white, opaque, polypropylene vessel. For initial sedimentation tests, a 2 L water sample was collected from Weston Park Lake (WPL), Sheffield, UK ( $53^{\circ} 22^{\prime} 56.849^{\prime \prime}$ N, $1^{\circ} 29^{\prime} 21.235^{\prime \prime}$ W), on 16th April 2014 during a bloom event. For subsequent sedimentation, eFLOAT, and resource analysis, $50 \mathrm{~L}$ of water was collected from a water retention pond (WRP) in the UK during a bloom event on 19th May 2014.

\subsection{Measurement of Water Retention Pond Abiotic and Biotic Variables}

The temperature, $\mathrm{pH}$, dissolved oxygen (DO), conductivity and salinity of WRP sample were measured with a Professional Plus Quatro (YSI, Yellow Springs, OH, USA). A $50 \mathrm{~mL}$ aliquot was collected, filtered with a Minisart High Flow $0.45 \mu \mathrm{m}$ syringe filter (Sartorius, Germany), and analysed for ammonium $\left(\mathrm{NH}_{4}^{+}\right)$, bromide $\left(\mathrm{Br}^{-}\right)$, calcium $\left(\mathrm{Ca}^{2+}\right)$, chloride $\left(\mathrm{Cl}^{-}\right)$, fluoride $\left(\mathrm{F}^{-}\right)$, magnesium $\left(\mathrm{Mg}^{2+}\right)$, nitrate $\left(\mathrm{NO}_{3}{ }^{-}\right)$, nitrite $\left(\mathrm{NO}_{2}{ }^{-}\right)$, phosphate $\left(\mathrm{PO}_{4}{ }^{3-}\right)$, potassium $\left(\mathrm{K}^{+}\right)$, sodium $\left(\mathrm{Na}^{+}\right)$and sulphate $\left(\mathrm{SO}_{4}{ }^{2-}\right)$ concentrations using a Dionex ICS-3000 ion chromatograph (Thermo Fisher Scientific, Waltham, MA, USA). Anions were measured on an AG18 $2 \times 250 \mathrm{~mm}$ column with a flow rate of $0.25 \mathrm{~mL} \cdot \mathrm{min}^{-1}$ and $31.04 \mathrm{mM}$ potassium hydroxide as eluent. Cations were measured on a CS16 $4 \times 250 \mathrm{~mm}$ column with a flow rate of $0.36 \mathrm{~mL} \cdot \mathrm{min}^{-1}$ and $48 \mathrm{mM}$ methanesulfonic acid as eluent. To estimate microalgae (and cyanobacterial) abundance, Chlorophyl a ( $\mathrm{Chl} a)$ concentrations were calculated using methanol and glass bead cell disruption as outlined by Welburn et al. [21]. For dry cell weight measurement, a $50 \mathrm{~mL}$ aliquot of WRP was centrifuged at $3000 \times g$ for $10 \mathrm{~min}$ at $4{ }^{\circ} \mathrm{C}$, frozen at $-20^{\circ} \mathrm{C}$ and immediately freeze-dried in a Modulgo freeze dryer (Edwards, Crawley, UK) for $12 \mathrm{~h}$ and weighed.

\subsection{Pure Microalgae Cultivation and Preliminary Sedimentation Tests}

Chlamydomonas reinhardtii (CC-125, Chlamydomonas Resource Centre, University of Minnesota, Minneapolis, MN,), and Chlorella vulgaris (CCAP 211/12, Culture Collection of Algae and Protozoa, Oban, Scotland) strains were chosen for the pure culture tests because they are both laboratory representative strains of green algae. Cells were cultured using artificial freshwater growth medium 
(Table S1) in $250 \mathrm{~mL}$ conical flasks and under $70 \mu \mathrm{mol} \mathrm{m}{ }^{-2} \cdot \mathrm{s}^{-1}$ illumination ( $12 \mathrm{~h} \mathrm{light,} 12 \mathrm{~h}$ dark) on an orbital shaker at $110 \mathrm{rpm}$. Diluted to the same optical density $\left(600_{\mathrm{nm}}=0.5\right)$, both algal cultures and the WPL sample were subjected to two coagulating agents, alum, $\mathrm{Al}_{2}\left(\mathrm{SO}_{4}\right)_{3}\left(12.5 \mathrm{mg} \cdot \mathrm{L}^{-1}\right.$ to $\left.100 \mathrm{mg} \cdot \mathrm{L}^{-1}\right)$ and chitosan (1 mg. $\mathrm{L}^{-1}$ to $\left.6 \mathrm{mg} \cdot \mathrm{L}^{-1}\right)$ [18] by rapid mixing in a jar tester (Flocculator S6, Stuart, FL, USA) at $250 \mathrm{rpm}$ for $10 \mathrm{~min}$, followed by slow mixing at $100 \mathrm{rpm}$ for $5 \mathrm{~min}$, to promote cell aggregation. To create an environmental sample with a reduced bacterial concentration, $1 \mathrm{~L}$ of WPL water was centrifuged at $3000 \times g$ for $15 \mathrm{~min}$ to produce biomass-free water. A separate $1 \mathrm{~L}$ of WPL water was filtered with a $3 \mu \mathrm{m}$ pore size polycarbonate isopore membrane (EMD Millipore, Burlington, MA, USA) which would recover mostly algal biomass while allowing smaller free-living bacteria to pass through [22]. The recovered algae were subsequently re-suspended in $1 \mathrm{~L}$ of the biomass-free water. Bacterial cell numbers were verified using a Bright-Line glass haemocytometer (Hausser Scientific, Horsham, PA, USA) on a BX 51 microscope (Olympus, Tokyo, Japan). A paired $t$-test was applied to identify statistically significant changes.

\subsection{WRP Sample Sedimentation and eFLOAT}

The WRP sample was flocculated with chitosan using the aforementioned procedure with concentrations of 1 to $9 \mathrm{mg} \cdot \mathrm{L}^{-1}$. This range of concentrations was tested to select two sedimentation efficiencies for the microflotation stage, a high sedimentation efficiency $\left(\mathrm{SE}_{\max }\right.$ ) and a lower efficiency $\left(\mathrm{SE}_{\text {sub-max }}\right)$. Following flocculation, eFLOAT was applied temporally at both $\mathrm{SE}_{\max }$ and $\mathrm{SE}_{\text {sub-max }}$ chitosan concentrations (including a blank where no chitosan was added), sampling every 2 min for $10 \mathrm{~min}$ (in duplicate). A laboratory-scale eFLOAT system was constructed from a Perspex flotation column, measuring $9 \mathrm{~cm}$ in diameter $\times 30 \mathrm{~cm}$ in height, with a microbubble ceramic diffuser (Point 4 MBD systems, mesoporous ceramic, 2-10 $\mu \mathrm{m}$ pore size, with SEM picture provided by Brittle et al. [23]) and sampling port (Supplementary Figure S1). A $2.2 \mathrm{~kW}$ compressor with cylinder size $0.1 \mathrm{~m}^{3}$ and duty cycle (50\%) 4 bars was used to pass compressed air through the fluidic oscillator and a portion of the air $\left(1 \mathrm{~mL} \cdot \mathrm{min}^{-1}\right)$ fed into the microporous diffuser, where it exited as microbubbles. During eFLOAT, $1 \mathrm{~L}$ of the sample was poured into the flotation column before introducing microbubbles.

\subsection{Biochemical Composition}

Analyses of the biochemical composition of the WRP sample was undertaken using methods described previously [24]. Briefly, a predetermined volume of the environmental samples were filtered onto a precombusted $13 \mathrm{~mm} \mathrm{A/E} \mathrm{glass} \mathrm{fiber} \mathrm{filter} \mathrm{paper} \mathrm{(Pall} \mathrm{Corporation,} \mathrm{Cortland,} \mathrm{NY,}$ USA) at room temperature, dried at $60{ }^{\circ} \mathrm{C}$ for $24 \mathrm{~h}$, wrapped in tin discs (Exeter Analytical, UK) and analyzed for total nitrogen (N) and total carbon (C) using a SerCon GSL elemental analyser $\left(1000{ }^{\circ} \mathrm{C}\right)$ interfaced with a $20-20$ Isotope Ratio Mass Spectrometer (PDZ-Europa, Northwich, Cheshire, UK). Isoleucine standards with known C:N ratios were used to calibrate measurements. Protein content was calculated by a nitrogen to protein conversion (4.78) [25]. Results were averages of three technical replicates. Soluble organic P measurements were made by converting organic $P$ from the environmental biomass on precombusted glass filters to orthophosphate, by digesting with acidic persulfate. A phospho-molybdate assay was used for measurements at $880 \mathrm{~nm}$ [26]. Total lipids were measured gravimetrically using a method based on chloroform and methanol [27] with modifications [24].

\subsection{Fatty Acid Methyl Ester Composition}

All chemicals and analytical reagents were of high performance liquid chromatography grade (Sigma-Aldrich, Dorset, UK) unless stated otherwise. Biomass samples $(15 \mathrm{~mL})$ were pelleted by centrifugation at $19,000 \times g$ for $3 \mathrm{~min}$ to which $1.2 \mathrm{~mL}$ of a methanol:chloroform $(1: 2, v / v)$ and equal volume of glass beads (425-600 $\mu \mathrm{m}$, acid washed) were added. Cells were disrupted with a Genie cell disruptor (Scientific Industries Inc., Bohemia, NY, USA) for 15 cycles (1 min bead beating and 
$1 \mathrm{~min}$ stand in ice bath). After cell disruption, the supernatant was collected after centrifugation at $19,000 \times g$, at $4{ }^{\circ} \mathrm{C}$ for $10 \mathrm{~min}$ and added to $800 \mu \mathrm{L}$ of chloroform and water $(1: 1 \mathrm{v} / \mathrm{v})$. After further centrifugation $\left(8000 \times \mathrm{g}\right.$ at $4{ }^{\circ} \mathrm{C}$ for $\left.10 \mathrm{~min}\right)$ the organic phase was pre-weighed prior to evaporation under inert nitrogen gas using a six port mini-vap evaporator (Sigma-Aldrich, Dorset, UK) and stored at $-80{ }^{\circ} \mathrm{C}$ until further analysis. The extracted lipids were converted into fatty acid methyl esters (FAMEs) [28] with minor modifications: $250 \mu \mathrm{L}$ of chloroform:methanol $(1: 1, v / v)$ and $100 \mu \mathrm{L}$ of $10 \%$ $(w / v) \mathrm{BF}_{3} /$ methanol was added to the dried extract and incubated at $80^{\circ} \mathrm{C}$ for $90 \mathrm{~min}$. After cooling, $300 \mu \mathrm{L}$ water and $600 \mu \mathrm{L}$ hexane were added, centrifuged $\left(18,000 \times g\right.$ at $4{ }^{\circ} \mathrm{C}$ for $\left.10 \mathrm{~min}\right)$ and $500 \mu \mathrm{L}$ of the organic phase removed and evaporated to dryness under inert nitrogen gas. The dried FAMEs were reconstituted in $100 \mu \mathrm{L}$ hexane prior to identification and quantification on a TRACE 1300 gas chromatography flame ionization detector (GC-FID) System (Thermo Scientific, Hertfordshire, UK) using a TR-FAME capillary column $(25 \mathrm{~m} \times 0.32 \mathrm{~mm} \times 0.25 \mu \mathrm{m}) .1 \mu \mathrm{L}$ derivatized sample was injected in split injection mode at $250{ }^{\circ} \mathrm{C}$ (split flow $75 \mathrm{~mL} \cdot \mathrm{min}^{-1}$ and purge flow $5 \mathrm{~mL} \cdot \mathrm{min}^{-1}$ ). The GC-FID was operated at a constant flow of $1.5 \mathrm{~mL} \cdot \mathrm{min}^{-1}$ helium at an initial temperature of $150{ }^{\circ} \mathrm{C}$ for $1 \mathrm{~min}$, followed by ramping at $10^{\circ} \mathrm{C} \cdot \mathrm{min}^{-1}$ to $250{ }^{\circ} \mathrm{C}$ and held constant here for $1 \mathrm{~min}$. Peak identities were ascertained using an external standard 37 component FAME mix (Supelco, Bellefonte, PA, USA) and peak areas were integrated using a chromatography data system (Thermo Scientific Dionex ChromeleonTM 7 software, Version 7.2.0.4154). In total, five technical replicates were run, among which only the FAMEs identified in 3 or more replicates were considered true hits.

\subsection{Microbial Diversity Analysis (16S and $18 S$ rDNA Gene Sequencing)}

DNA extractions for microbial diversity analysis were performed on biomass taken from (i) WRP (day 0), (ii) non-chitosan treatment blank (day 10) (iii) Sub-max chitosan treatment (day 10) and (iv) max chitosan treatment (day 10). Conditions (ii) to (iv) were undertaken in duplicate. DNA was extracted with a standard phenol-chloroform extraction protocol (Sambrook and Russel, 2001). PCR amplification, product pooling, purification and sequencing were performed by RTL Genomics (Lubbock, TX, USA) using an Illumina MiSeq (Illumina, Inc. San Diego, CA, USA) and as described previously [29]. Bioinformatic and statistical analysis involved merging the forward and reverse reads [30] and filtering for quality and clustering using the USEARCH algorithm [31]. Chimeras were removed using the UCHIME chimera detection software executed in de novo mode [32] with reads mapped using the USEARCH global alignment algorithm [31]. Searches were performed using an in-house curated database retrieved from NCBI (17th October 2015). Finally, the OTU table output from sequence clustering was collated with the taxonomic information [33] as described previously [29]. The SEED algorithm was applied to create PCA plots for genus level taxa present above $1 \%$ relative abundance [34]. Shannon diversity indices $\left(\mathrm{H}^{\prime}\right)$ were calculated to express diversity within the samples as described previously [35].

\section{Results}

\subsection{Preliminary Sedimentation Tests with Pure Microalgae and WPL Sample}

Flocculation efficiencies were calculated for the removal of pure algal cultures (Chlorella and Chlamydomonas) and an environmental biomass sample from WPL ( $\mathrm{pH} 7$ ) using a range of chitosan and alum concentrations (Figure 1). Lower concentrations of chitosan were required to achieve higher flocculation efficiencies with WPL (Figure 1A). The $1 \mathrm{mg} \cdot \mathrm{L}^{-1}$ sample of chitosan achieved $85 \% \mathrm{Chl} a$ removal from the WPL compared with just $46 \%$ and $22 \%$ removal from Chlamydomonas and Chlorella cell cultures, respectively. Interestingly, the same effect was not observed for alum. When compared to the WPL samples both Chlorella and Chlamydomonas cells flocculated with significantly higher efficiency at concentrations of alum ranging from $12.5-100 \mathrm{mg} \cdot \mathrm{mL}^{-1}(p<0.01)$. Similar to a previous study, these preliminary tests suggest chitosan is more efficient for flocculation of the WPL sample, under the conditions tested [36]. 


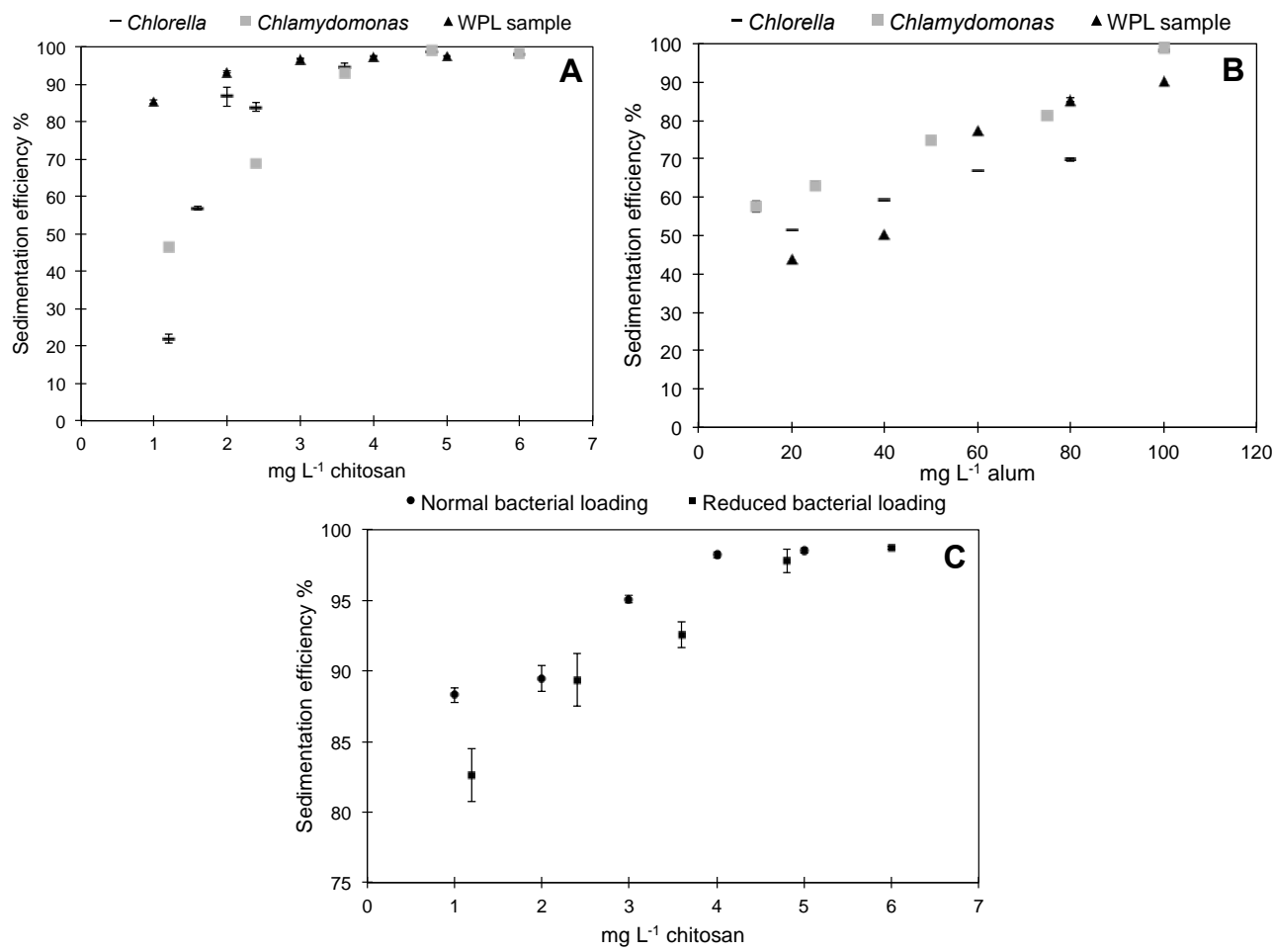

Figure 1. Preliminary sedimentation efficiency experiments using (A) Chitosan with Chlorella, Chlamydomonas and WPL sample, (B) Alum with Chlorella, Chlamydomonas and Weston Park Lake (WPL) sample and (C) Chitosan with WPL sample with normal and reduced bacteria concentration (error bars are standard deviation $n=3$ ).

It has been demonstrated previously that bacteria within algal cultures can aid the flocculation process by forming microalgal bacterial flocs inducing sedimentation [37]. In this study, we hypothesized that the presence of bacteria within the WPL sample could improve flocculation efficiency when adding a flocculant, as the resulting bacterial surface charge neutralization could combine with algal cells to form larger aggregates and hence aid sedimentation. In addition, the extracellular metabolites and/or proteins within the water could act as organic polymers to promote flocculation. We compared chitosan-induced flocculation with WPL samples containing natural and reduced concentrations of bacteria. Microscope images showed an $82 \pm 13 \%$ decrease in bacterial cell numbers using the filtering method. The presence of more bacteria implied a positive effect and significantly improved flocculation efficiency at chitosan doses of $1 \mathrm{mg} \cdot \mathrm{mL}^{-1}(p=0.027)$ with no significant difference in concentrations above $2 \mathrm{mg} \cdot \mathrm{mL}^{-1}$ (Figure 1C). Further work would need to be undertaken to distinguish between the specific roles of both extracellular metabolites and bacteria in flocculation.

\subsection{WRP Pond Sedimentation Test and eFLOAT}

The final sedimentation test was undertaken to identify the chitosan concentrations that would provide maximum sedimentation efficiency $\left(\mathrm{SE}_{\max }\right)$ and a reduced sedimentation efficiency $\left(\mathrm{SE}_{\text {sub-max }}\right)$ with the WRP sample. A $\mathrm{SE}_{\text {sub-max }}$ chitosan concentration was calculated to alter the application methodology of eFLOAT, where reduced sedimentation efficiency can, potentially, lower application costs and still provide resource and environmental recovery. Also, the reduced harvesting would lessen the impact of the non-selective harvesting approach, and potentially allow the ecosystem to recover more rapidly from eFLOAT. Based on these results, chitosan concentrations of 1.25 and $5 \mathrm{mg} \cdot \mathrm{L}^{-1}$ were selected for the eFLOAT experiment as they represented a $70 \%\left(\mathrm{SE}_{\text {sub-max }}\right)$ and $96 \%\left(\mathrm{SE}_{\max }\right)$ sedimentation efficiency, respectively (Figure 2A). 

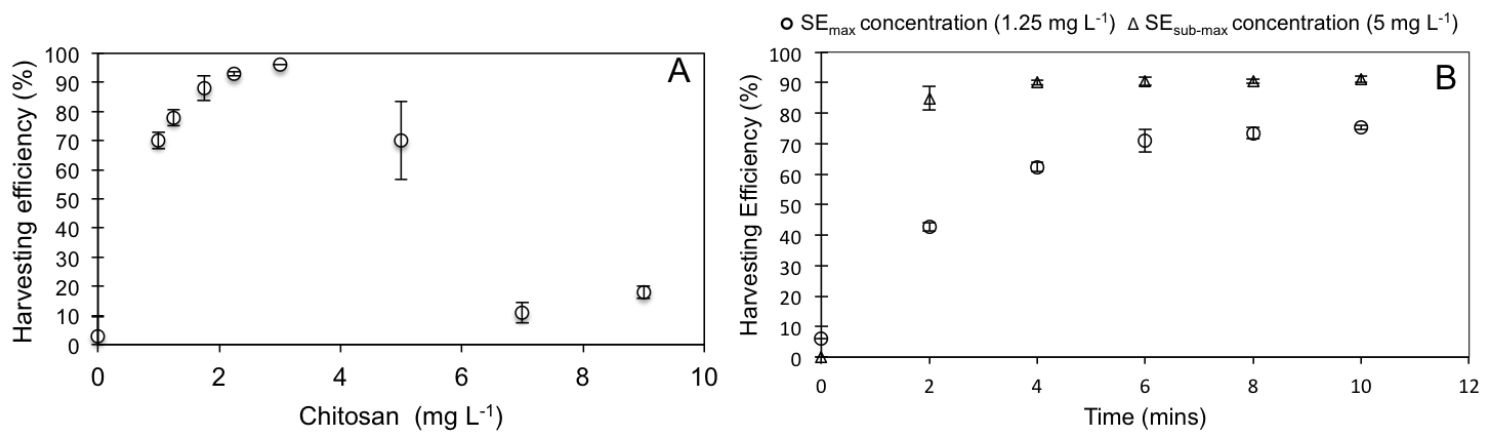

Figure 2. WRP sample tests (A) Sedimentation efficiency using chitosan (B) eFLOAT harvesting efficiency at $\mathrm{SE}_{\max }$ and $\mathrm{SE}_{\text {sub-max }}$ chitosan concentrations.

The physicochemical characteristics of the WRP are shown in Table 1. A combination of temperature $\left(18.1^{\circ} \mathrm{C}\right)$, season (Spring), and extremely high $\mathrm{PO}_{4}{ }^{3-}$ levels $\left(6.11 \mathrm{mg} \cdot \mathrm{L}^{-1}\right)$ contributed to a high concentration of $\mathrm{Chl} a$ at $443.32 \mu \mathrm{g} \cdot \mathrm{L}^{-1}$. A time-series eFLOAT experiment was undertaken with this sample using $\mathrm{SE}_{\max }\left(5 \mathrm{mg} \cdot \mathrm{L}^{-1}\right)$ and $\mathrm{SE}_{\text {sub-max }}\left(1.25 \mathrm{mg} \cdot \mathrm{L}^{-1}\right)$ chitosan concentrations (Figure $2 \mathrm{~B}$ ). After $10 \mathrm{~min}$, the harvesting efficiencies using microflotation for $\mathrm{SE}_{\max }$ and $\mathrm{SE}_{\text {sub-max }}$ concentrations of chitosan were $91.2 \%$ and $75.3 \%$, respectively. These harvesting efficiency values were similar to those seen in the sedimentation test (Figure 2A), and therefore provided validation for using sedimentation data to guide eFLOAT parameters for WRP samples. The major difference between $\mathrm{SE}_{\max }$ and $\mathrm{SE}_{\text {sub-max }}$ in the eFLOAT experiment was the time taken to reach the highest harvesting efficiency. Within 2 min $\mathrm{SE}_{\max }$ led to $84.9 \%$ harvesting efficiency, whereas $\mathrm{SE}_{\text {sub-max }}$ levels only achieved a harvesting efficiency of $42.7 \%$. By 10 min both $\mathrm{SE}_{\max }$ and $\mathrm{SE}_{\text {sub-max }}$ chitosan concentrations were more similar (harvesting efficiencies of $91.2 \%$ and $75.3 \%$, respectively). This implies that, given enough time, using a third of the higher chitosan concentration value can still recover up to $75 \%$ of the environmental biomass in the eutrophic water system tested. It is important to note that due to the mechanism of chitosan-induced flocculation (i.e., adsorption and charge neutralization between positively charged chitosan in water, and negatively charged algal/bacterial cell surfaces [38]), these chosen parameters are highly dependent on the nature of the environmental sample in terms of total biomass, species present, growth stage (i.e., variable cell surface characteristics affecting zeta potentials) and water physicochemistry (e.g., $\mathrm{pH}$, temperature, salt ions etc.) [39]. This is why preliminary investigative sedimentation experiments are routinely undertaken by the water treatment industry. The time of year when the bloom occurs is also an important factor, as microalgae tend to dominate early spring and summer blooms, whereas cyanobacteria are more prevalent during late summer.

Table 1. Detailed physicochemical characterization of water retention pond (WRP) during a bloom event (19th May 2014).

\begin{tabular}{cccc}
\hline Parameter & Value & SD & Unit \\
\hline Temperature & 18.1 & - & ${ }^{\circ} \mathrm{C}$ \\
pH & 7.01 & - & \\
DO & 9.86 & - & $\mathrm{mg} \cdot \mathrm{L}^{-1}$ \\
Conductivity & 302.1 & - & $\mu \mathrm{S} \cdot \mathrm{cm}^{-1}$ \\
Salinity & 0.17 & - & $\mathrm{PSU}$ \\
Dry Weight & 0.13 & 0.003 & $\mathrm{~g} \cdot \mathrm{L}^{-1}$ \\
Chlorophyll $a$ & 443.23 & - & $\mathrm{\mu g} \cdot \mathrm{L}^{-1}$ \\
$\mathrm{~F}^{-}$ & 0.00 & 0.00 & $\mathrm{mg} \cdot \mathrm{L}^{-1}$ \\
$\mathrm{Cl}^{-}$ & 26.49 & 0.21 & $\mathrm{mg} \cdot \mathrm{L}^{-1}$ \\
$\mathrm{NO}_{2}{ }^{-}$ & 9.72 & 0.02 & $\mathrm{mg} \cdot \mathrm{L}^{-1}$ \\
$\mathrm{SO}_{4}{ }^{2-}$ & 6.00 & 0.04 & $\mathrm{mg} \cdot \mathrm{L}^{-1}$ \\
$\mathrm{Br}^{-}$ & 0.00 & 0.00 & $\mathrm{mg} \cdot \mathrm{L}^{-1}$ \\
\hline
\end{tabular}


Table 1. Cont.

\begin{tabular}{cccc}
\hline Parameter & Value & SD & Unit \\
\hline $\mathrm{NO}_{3}{ }^{-}$ & 2.59 & 0.04 & $\mathrm{mg} \cdot \mathrm{L}^{-1}$ \\
$\mathrm{PO}_{4}{ }^{3-}$ & 6.11 & 0.02 & $\mathrm{mg} \cdot \mathrm{L}^{-1}$ \\
$\mathrm{Na}^{+}$ & 16.85 & 0.10 & $\mathrm{mg} \cdot \mathrm{L}^{-1}$ \\
$\mathrm{NH}_{4}{ }^{+}$ & 0.48 & 0.02 & $\mathrm{mg} \cdot \mathrm{L}^{-1}$ \\
$\mathrm{~K}^{+}$ & 4.02 & 0.06 & $\mathrm{mg} \cdot \mathrm{L}^{-1}$ \\
$\mathrm{Mg}^{2+}$ & 9.15 & 0.00 & $\mathrm{mg} \cdot \mathrm{L}^{-1}$ \\
$\mathrm{Ca}^{2+}$ & 37.42 & 0.01 & $\mathrm{mg} \cdot \mathrm{L}^{-1}$ \\
\hline
\end{tabular}

\subsection{Resource Analysis}

Considering a fluctuating volume of water within the WRP phototrophic zone of 5000 to $10,000 \mathrm{~m}^{3}$, and assuming an even distribution of algal biomass during a bloom event, a dry biomass weight of $0.13 \mathrm{~g} \cdot \mathrm{L}^{-1}$ equates to approximately 650 to $1300 \mathrm{~kg}$ biomass dry weight for the WRP. A relatively high $\mathrm{Chl} a$ concentration of $443.23 \mu \mathrm{g} \cdot \mathrm{L}^{-1}$ was not unexpected as the $\mathrm{PO}_{4}{ }^{3-}$ concentration was $6.11 \mathrm{mg} \cdot \mathrm{L}^{-1}$ (Table 1). This high concentration is likely due to high levels of agricultural nutrient run-off from surrounding areas.

Arguably, the simplest (from a regulatory and technical perspective) use of environmental waste biomass is recycling to agricultural land (soil restorer) or as a feedstock in anaerobic digesters (biomethane production). However, microalgae are a highly diverse group of organisms with an assorted array of uses [20]. Their lipids can be readily converted to biodiesel [40] and also provide precursors for industrial chemicals [41-44]. Their cells can be processed to extract phosphorus for fertilizer $[45,46]$ and algal protein has been found to be an attractive food replacement for the unsustainable feedstock presently used for fish and farm animals [47], although regulatory issues would need to be considered here. To gain insight into the resource potential, a biochemical analysis of cells from the WRP sample was undertaken (total lipid, P, and proteins). Furthermore, the FAME composition was characterized and compared to values from pure cultures within the literature (Table S2).

\subsubsection{Total Lipids and FAME Analyses}

Prior to FAME analysis, total lipid content in the WRP biomass was calculated at $103.7 \pm 1.28 \mu \mathrm{g} \cdot \mathrm{mg}^{-1}$ biomass using the gravimetric method. Considering the estimated total biomass of 650 to $1300 \mathrm{~kg}$ dry weight within the WRP, and the lipid content within its biomass, maximum harvesting using eFLOAT would potentially recover 61-123 kg lipids and sub-max harvesting 51-102 kg lipids.

The fatty acid composition of the environmentally-sourced biomass in this study was analyzed and compared to FAME composition analyses of pure cultures that have been published in the literature (Table S2). The general pattern is similar to pure cultures with the chain length being dominated by C16 and C18 fatty acids. This was expected, as microalgae typically produce saturated and unsaturated versions with these chain lengths [41]. There were differences, for example, 19.3\% of WRP biomass contained C14:0 FAME, considerably higher than typically seen in the previously published studies with freshwater microalgae, and more typical of marine species such as Isochrysis galbana $(14.4 \%)$, Emiliana huxleyi (18.8\%) and Nannochloris sp. (13.3\%) (Table S2). This general overview demonstrates that the FAMEs extracted from environmentally sourced algal biomass have comparable composition to pure algal cultures. Despite this, environmental conditions play a significant role in the FAME composition of microalgal cells [48], and a more comprehensive understanding of this phenomenon could be used to identify the most appropriate resource type for harvested biomass.

To further investigate FAME-related resource potential of the WRP biomass, they were grouped into monounsaturated fatty acids (MUFAs), polyunsaturated fatty acids (PUFAs), and saturated fatty acids (SFAs) by productivity yields (Figure 3), as they represent different potential resources. The biomass had relatively high levels of the MUFA C18:1 cis or oleic acid (13.3 $\mathrm{mg} \cdot \mathrm{g}^{-1}$ biomass). 
Oleic acid is commonly found in olive oil and in its sodium salt form it is used as an emulsifying agent within soaps. It has also been used within cosmetic products for its moisturizing qualities [49]. The biomass was also relatively rich in PUFA C18:3n $3\left(32.5 \mathrm{mg} \cdot \mathrm{g}^{-1}\right.$ biomass). In addition, C18:3n 3 or $\alpha$-linolenic acid is an omega- 3 fatty acid, essential for the human diet and found in seeds, nuts, and vegetable oils.

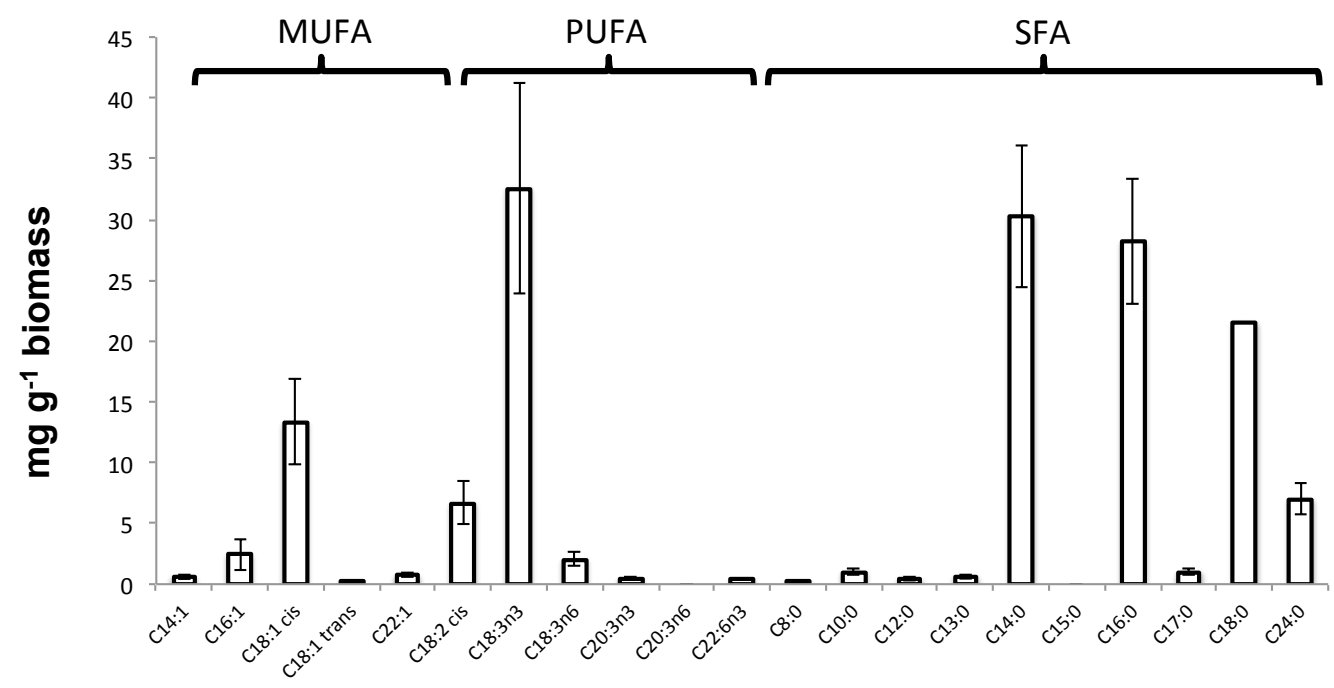

FAME

Figure 3. Total FAMEs within biomass sample, characterized as monounsaturated fatty acids (MUFAs), polyunsaturated fatty acids (PUFAs) and saturated fatty acids (SFAs).

The largest values in terms of $\mathrm{mg} \cdot \mathrm{g}^{-1}$ biomass were seen for groups of SFAs including C14:0, C16:0 and C18:0 (30.29, 28.17 and $21.5 \mathrm{mg} \cdot \mathrm{g}^{-1}$ biomass, respectively). This was perhaps not surprising considering C16:0 or palmitic acid is the most common SFA present in plants, animals, and microorganisms. Industrially, palmitic acid has many uses, for example, in the manufacture of detergents or cosmetics, and is mostly sourced from palm oil. C14:0 or myristic acid is used to synthesize flavor and is an ingredient in soaps and cosmetics, whereas C18:0 or stearic acid is widely used within soaps, cosmetics, and detergents through saponification of TAGs from stearic acid esters.

\subsubsection{Phosphorus Content Analyses}

The nutrient $\mathrm{P}$ accumulated within the biomass was also considered a recoverable resource. The amount of $\mathrm{PO}_{4}{ }^{3-}$ present in the water sample (Table 1), as well as soluble organic-P present within the recovered algal biomass, was quantified. The WRP contained a concentration of $\mathrm{PO}_{4}{ }^{3-}$ $\left(6110 \mu \mathrm{g} \cdot \mathrm{L}^{-1}\right)$ and perhaps unsurprisingly its biomass also contained a high concentration of $9.02 \mu \mathrm{g} \cdot \mathrm{mg}^{-1}$ biomass. Considering the estimated total biomass of 650 to $1300 \mathrm{~kg}$ dry weight within the WRP, maximum harvesting using eFLOAT could potentially recover 5.35-10.69 $\mathrm{kg} \mathrm{PO}_{4}{ }^{3-}$ and sub-max harvesting 4.41-8.83 $\mathrm{kg} \mathrm{PO}_{4}{ }^{3-}$. The removal efficiency of $\mathrm{PO}_{4}{ }^{3-}$ in the P-rich WRP sample during the 15 min eFLOAT experiment was calculated to be $14.4 \%$ (sub-max) and $17.5 \%$ (max), indicating that repeat harvesting could be undertaken as P-levels would be high enough to support further blooms.

\subsubsection{Protein Content Analyses}

Algae have been coveted as a protein feed since comprehensive studies on pure cultures have demonstrated that they have high nutritional quality [50]. The protein content of recovered algal biomass was quantified at $325.45 \pm 28.63 \mu \mathrm{g} \cdot \mathrm{mg}^{-1}$ biomass. Based on the estimated biomass within the WRP, a maximum harvesting using eFLOAT would potentially recover 192.93-385.69 kg protein at the time of sampling, and sub-max harvesting would recover $159.29-318.50 \mathrm{~kg}$ protein. The exact 
recoverable and usable protein resource would depend upon the specific protein characteristics and efficiency of downstream processes for extraction and purification from algal biomass.

\subsubsection{Microbial Diversity Analysis}

The importance of the relationship between microbial community diversity and multiple ecosystem functions has only recently been investigated due to advanced molecular sequencing techniques. A recent study provided empirical evidence that any loss in microbial diversity can lead to reduced multi-functionality, negatively impacting any ecosystem services provided [19]. Microbial diversity has been used as a bio-indicator for aquatic ecosystem health previously [51], and algal blooms have been linked to reduced biodiversity. Recently, we have shown that bacteria-driven function is impacted by the nutrient status of aquatic environments [29]. Moreover, despite the motivation of eFLOAT being the removal of polluting algal biomass, the harvesting parameters identified in Sections 3.1 and 3.2 could target specific microbial groups. To assess the impacts of the sub-maximum and maximum harvesting parameters on microbial composition and diversity, $16 \mathrm{~S}$ rDNA and $18 \mathrm{~S}$ rDNA sequencing analysis was undertaken at Day 0 and 10 days after sub-maximum and maximum harvesting had taken place. A control was also included where no harvesting treatment was performed. This data was supported by $\mathrm{Chl} a$ measurements. As expected, $\mathrm{Chl} a$ measurements for the blank treated samples were very similar to the initial concentrations in the WRP $\left(395.7 \pm 12.2 \mathrm{ug} \cdot \mathrm{L}^{-1}\right.$ versus $443.23 \mathrm{ug} \cdot \mathrm{L}^{-1}$ respectively). Sub-maximum and maximum harvesting reduced overall Chl $a$ by $65.2 \pm 2.8 \%$ and $82.2 \pm 5.4 \%$, respectively (Table S3). Hence, the harvesting did remove a large proportion of the algal biomass, and this remained the case 10 days post-treatment.

In regards to the microbial community composition, Figure 4 shows the relative abundance of bacterial and eukaryotic biota in the WRP (day 0), where no harvesting (control) was performed, and where sub-maximum and maximum harvesting (after 10 days) were undertaken. The average number of reads for these samples was 67,687 with a mean length of 414 base pairs. A scatter plot of coordinates (PCoA) groups diversity between biological replicates, providing confidence in the results (Figure S2). Most notably, bacterial diversity was dominated by the cyanobacterium Synechococcus in the WRP (day 0) and the control samples (day 10). Sub-maximum harvesting reduced this by more than 2-fold, and their presence was all but eliminated in the maximum harvesting samples. This resulted in an increase in diversity, reflected by an increased Shannon diversity index. Interestingly, the population identities were very different between the replicate maximum harvesting samples after 10 days incubation (Figure 4). Eukaryotic diversity showed clear dominance from the Chlorophyta class in all samples (Figure 4). These results were less clear to interpret due to the high number of sequences that were not matched and the high level of variation between biological replicates illustrated by PCoA analysis (Figure S2).

Algal blooms are viewed as problematic principally due to the production of toxins by certain species, mostly cyanobacterial. However, the impact of blooms on aquatic biodiversity is also a major cause for concern. The data presented here provides insight into how the microbial community (and function) changes from an undesirable alga-dominated system (pre-harvesting) to a bacterial/algae-based system (post-harvesting), particularly with maximum harvesting. There was no evidence that the parameters applied targeted specific microbial groups. The variability between replicates in the bacterial community 10 days after maximum harvesting demonstrates the complexity of microbial ecological succession in aquatic environments [52]. 

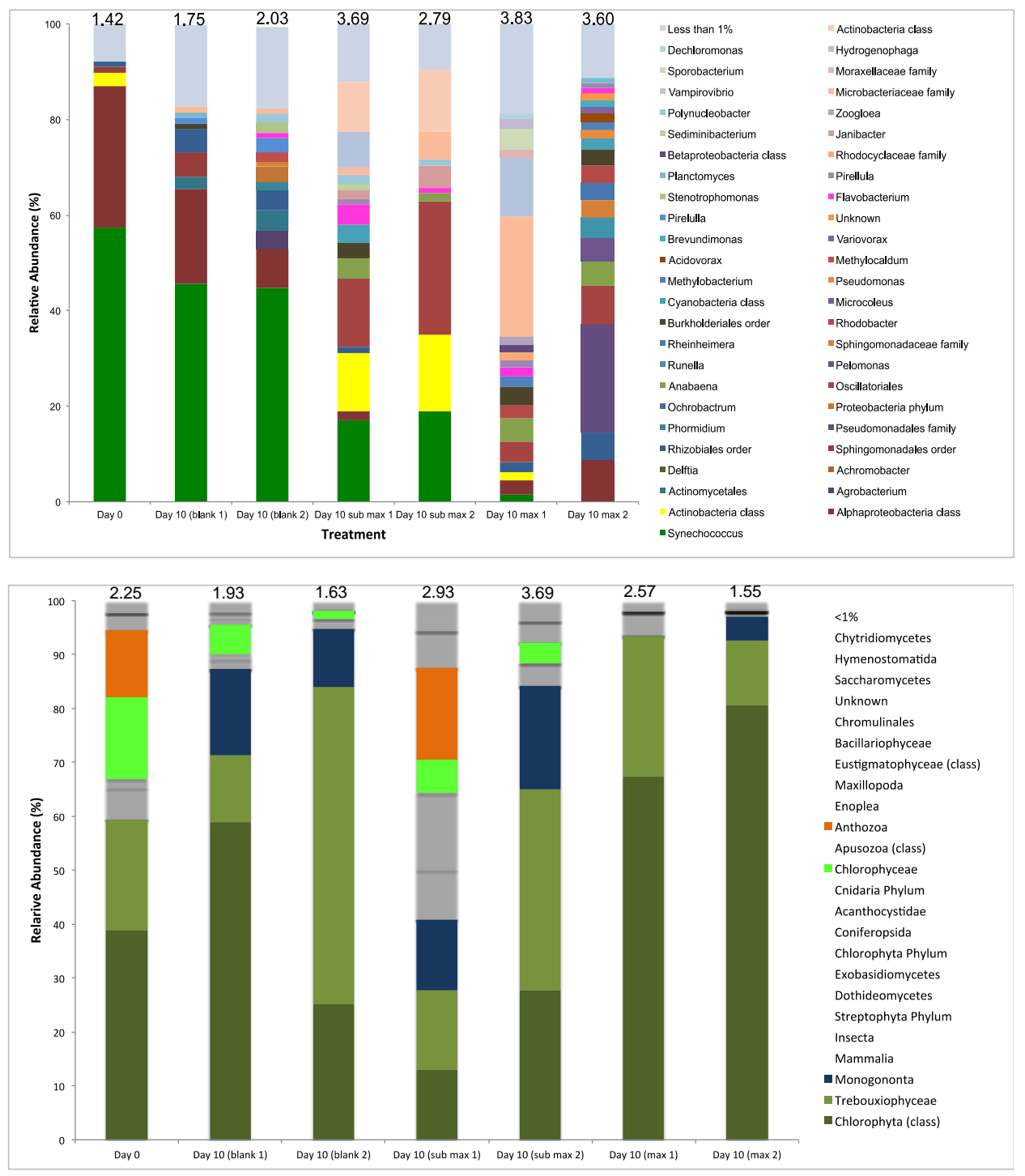

Figure 4. Relative gene abundance (\%) of microorganisms identified within WRP sample, control (no harvesting), sub-maximum harvesting, and maximum harvesting (in biological replicates). The 16S rDNA bacterial abundance is shown at a genus level except when indicated (top) and 18S rDNA eukaryotic abundance is shown at a class level except when indicated (bottom). Algae (eukaryotic microalgae and prokaryotic cyanobacteria) are shown in shades of green. The Shannon diversity indices based on OTUs are shown at the top of each column.

\subsection{A Full Size Modular eFLOAT System}

Although the resource analysis has detailed a number of useful products that could be harvested from the algal biomass, in most scenarios the overriding driver for biomass harvesting from the water body is for remediation i.e., the algal removal is a preventative or responsive ecosystem treatment. Given the scale of many of the components of the system, it is interesting to consider a modular eFLOAT pontoon-style system that would be capable of being flexibly scaled up or down, to meet the size requirements of a particular lake. Robust construction, ability to handle a wide range of weather conditions, low operational costs, and ease of repair, are all important design considerations for the modular units.

In terms of scale for a batch treatment enclosure for each pontoon, Zimmerman et al. provide a useful reference point, where a pilot plant tank of 24,000 L was used to investigate the efficacy of 
membrane-based microbubbles to increase gaseous mass transfer [17]. This provides a reasonably sized volume to treat in a batch mode with eFLOAT. Laboratory-based analysis suggests that eFLOAT air requirements is $1 \mathrm{~mL} \cdot \mathrm{min}^{-1}$ to treat $1 \mathrm{~L}$, which, when scaled up to a treatment volume of $24,000 \mathrm{~L}$, would equate to an air supply requirement of $24 \mathrm{~L}$ of air $\mathrm{min}^{-1}$ at a pressure of $3 \mathrm{bar}(\mathrm{g})$ (Figure 5). The air volume and pressure to accommodate this airflow would be covered by a $7.1 \mathrm{cfm}\left(201 \mathrm{~L} \cdot \mathrm{min}^{-1}\right)$ compressor with a $110 \mathrm{~V}$ input and $1.1 \mathrm{~kW}$ load rating. The airflow rating at $3 \mathrm{bar}(\mathrm{g})$ will be approximately $25 \%$ of this value, which equates to $50 \mathrm{~L} \cdot \mathrm{min}^{-1}$. An additional electrical load would be the pond skimmer that floats within the enclosure and skims the floating algae to a separation tank at the appropriate time (depending on bloom size) during each batch process, as well as a pump to deliver and remove water from the eFLOAT tank. The overall timing of the harvesting process for $24,000 \mathrm{~L}$ is predicted to be $30 \mathrm{~min}$, with an additional $48 \mathrm{~min}$ to introduce and also to remove the water from the eFLOAT tank (total $=126 \mathrm{~min}$ ). The addition of flocculant during eFLOAT would be an extra consideration, and we have identified $5 \mathrm{mg} \cdot \mathrm{L}^{-1}$ chitosan as sufficient with the WRP sample within the laboratory scale rig. The cost of chitosan is estimated at $£ 30 \mathrm{Kg}^{-1}$ although this varies by quality and quantity purchased. Full capital expenditure (CAPEX) and operating expenditure (OPEX) figures are provided in Table 2 and for treatment of the WRP (assuming $7500 \mathrm{~m}^{3}$ water) for the full size modular eFLOAT system. A treatment of this volume would cost less than $£ 2000$ over a week. Moreover, costs can be reduced further using locally sourced flocculants, for example, modified local sands [53]. The exact efficiency of the process over a season, and therefore total operating costs, would vary depending on the type of bloom (i.e., species present, concentration of cells, etc.), chemistry of the water, and environmental conditions.

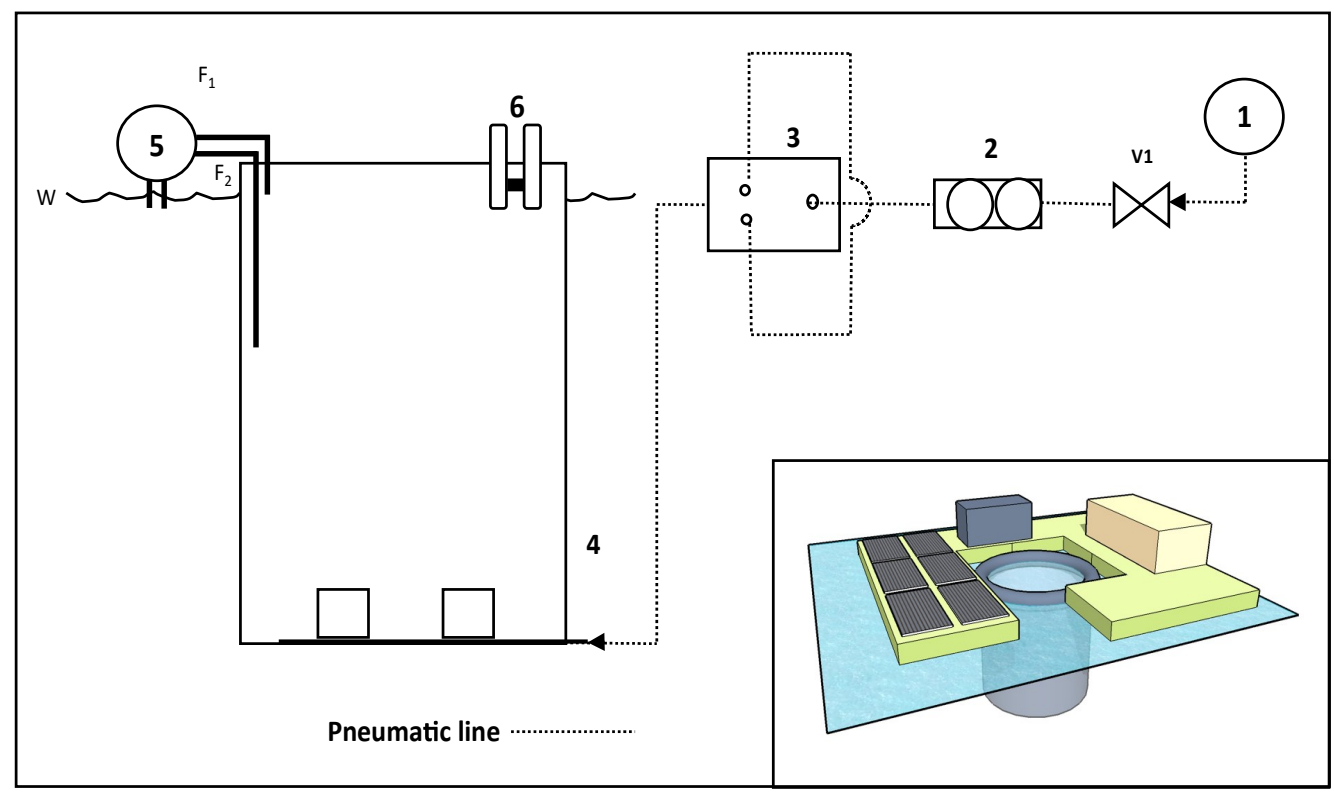

Figure 5. eFLOAT process based on a modular pontoon design (Inset: 3D eFLOAT design). Full capital expenditure (CAPEX) and operating expenditure (OPEX) figures are given in Table 2. 1. Compressor (50 L air compressor, $7.1 \mathrm{CFM}, 1.5 \mathrm{HP}, 1.1 \mathrm{~kW}, 110 \mathrm{~V}$ ); 2. Rotameter; 3. Fluidic oscillator (Pressure drop of $150 \mathrm{mbar}$ ); 4 . eFLOAT tank ( $24 \mathrm{~m}^{3}$ liquid capacity, $10 \%$ ullage for height, dimensions: $3 \mathrm{~m}$ diameter, $3.5 \mathrm{~m}$ height. $24 \mathrm{~L} \cdot \mathrm{min}^{-1}$ total air flow for the tank. $2 \times 0.4 \mu \mathrm{m} \mathrm{MBD600}$ diffusers. $12 \mathrm{~L} \cdot \mathrm{min}^{-1}$ average flow. $18 \mathrm{~L} \cdot \mathrm{min}^{-1}$ maximum rated flow; 5 . Pump-Introducing and removing water from the eFLOAT tank, $320 \mathrm{~W}$; 6. Skimmer-Recovering microalgal biomass, $27 \mathrm{~kW}$; $\mathrm{V}_{1}$. Shutdown valve; $\mathrm{F}_{1}$ (Flow in); $\mathrm{F}_{2}$ (Flow out); $\mathrm{W}$ (Water level). 
Table 2. CAPEX and OPEX of eFLOAT system based on one modular system treating $24,000 \mathrm{~L}$ water in $30 \mathrm{~min}$. (Figures are given as a guideline only).

\begin{tabular}{ccccc}
\hline Item & CAPEX $(\boldsymbol{(})$ & OPEX $(\mathfrak{( )})$ & Application Time $(\mathbf{m i n})$ & Full Cost for WRP (7.5 ML) \\
\hline Compressor & 200 & 0.83 & 30 & 259 \\
Rotameter & 60 & 0 & 30 & 0 \\
Fluidic oscillator & 100 & 0 & 30 & 0 \\
eFLOAT tank & $1420^{*}$ & 0 & $\mathrm{n} / \mathrm{a}$ & 0 \\
Pumps & 1000 & 0.077 & 96 & 24 \\
Skimmer & 1000 & $1.20^{* *}$ & 30 & 375 \\
Chitosan & $\mathrm{n} / \mathrm{a}$ & $30 \mathrm{Kg}^{-1}$ & 5 & 1125 \\
\hline
\end{tabular}

* 2 diffusers $(£ 210$ each $)+\operatorname{tank}(£ 1000) ;{ }^{* *} 16 \mathrm{~kW}$ for skimmer pump; Assuming $15 \mathrm{p} \mathrm{kWh}{ }^{-1}$.

These modular eFLOAT pontoons would ideally be powered by renewable energy, e.g., solar PV panels, and be deployed and managed by a single operator to harvest the biomass. In this manner, these could be quickly scaled and deployed to areas where algal blooms are prevalent. This design could be accommodated by 6-8 solar panels of $250+\mathrm{W}$ each, depending on the trade-off between capital costs and working timeframe in a given day. This is also dependent on the insolation values wherever in the world the system is deployed. The physical size of the solar panels would be somewhere between $8 \mathrm{~m}^{2}$ and $12 \mathrm{~m}^{2}$, dependent on the type of solar panel, and this is shown in the inset graphic of a modular pontoon in Figure 5.

Although most of the modular components of the eFLOAT pontoon concept are commercially available, the overall system has not been verified or optimized. Further research is required to establish how the airflow is impacted by changing the tank dimensions and by optimizing the system components and operating protocols for a range of different input conditions. Interesting research questions arise around the least number of solar panels that could be used, and the trade-off between the number of solar panels, pump size, air tank volume, and the rate at which a batch process could be undertaken.

\section{Conclusions}

This laboratory-scale study demonstrates that a combination of chitosan-induced flocculation and eFLOAT has the potential to remove polluting algal biomass from natural water systems, and a modular pontoon has been theorized. The application would be particularly useful in open lake or pond systems, similar to the WRP, where $\mathrm{PO}_{4}{ }^{3-}$ concentrations are very high $\left(\mathrm{mg} \cdot \mathrm{L}^{-1}\right.$ range). Therefore, this application could provide a treatment methodology where polluting $\mathrm{PO}_{4}{ }^{3-}$ is removed within algal biomass. We argue that the combined use of an environmentally-friendly flocculant, together with low energy requirements, would allow a scaling up the of the eFLOAT technology with a pontoon-style harvesting system. Although recovering a lake to healthy status would out-weigh the economic benefits of recovering resources, these do provide an additional incentive, and the technology could be applied to target specific microbial biomass suitable for valorization.

Supplementary Materials: The following are available online at www.mdpi.com/2079-7737/7/1/4/s1. Table S1: Complete composition of artificial freshwater growth medium. Table S2: A summary of FAME profiles between different microalgae species mostly focussing on recent studies. The studies were selected based on similar methodologies applied to sample processing steps, catalysts, GC columns and GC conditions. NB. Percentages will vary depending on the number of FAMEs quantified in each experiment and only the major FAMEs detected are shown for clarity in the comparison (see citation for more details of exact experimental procedures). Table S3: Chlorophyll $a$ measurements during eFLOAT long-term experiment. Figure S1: 1 litre eFLOAT Rig using during laboratory tests. Figure S2: Scatter plot of coordinates (PCoA) to show relative abundance (\%) variation between identified genus/class in biological replicate samples (A) Bacterial (16S rDNA sequencing) diversity (B) Eukaryotic (18S rDNA sequencing) diversity. HM: half max harvesting, M: max harvesting. Figure S3: Rarefaction plots for bacterial primers (28F-519R) and eukaryotic primers (565-981).

Acknowledgments: The authors would like to acknowledge NERC and TSB for funding (NE/K015591/1 and NE/J024767/1). We also thank Stephen Maberly for providing advice and water samples, Kenneth Hsu for discussions on the ecology and engineering of lake systems, and Gang Pan for sample provision and perspectives 
on ecological engineering approaches. Finally, we recognise Mark Jones for providing technical assistance and advice with GC-FID for FAME analyses.

Author Contributions: The research concept and experiments were devised by Jagroop Pandhal and Andrew S. Ferguson. Experimental work was undertaken by Wai L. Choon, Rahul V. Kapoore, David A. Russo and James Hanotu. Expertise in microflotation was provided by William J. Zimmerman and Pratik Desai, with Pratik Desai and I. A. Grant Wilson performing economic modelling. Jagroop Pandhal performed analysis of sequencing data and Malcolm Bailey provided industrial samples and information. Jagroop Pandhal wrote the manuscript.

Conflicts of Interest: The authors declare no conflict of interest. The founding sponsors had no role in the design of the study; in the collection, analyses, or interpretation of data; in the writing of the manuscript, and in the decision to publish the results.

\section{References}

1. Sutton, M.A. Our Nutrient World: The Challenge to Produce More Food and Energy with Less Pollution; Centre of Ecology and Hydrology: Bailrigg, UK, 2013; p. 114.

2. Yang, X.E.; Wu, X.; Hao, H.L.; He, Z.L. Mechanisms and assessment of water eutrophication. J. Zhejiang Univ.-Sci. B 2008, 9, 197-209. [CrossRef] [PubMed]

3. O'neil, J.M.; Davis, T.W.; Burford, M.A.; Gobler, C.J. The rise of harmful cyanobacteria blooms: The potential roles of eutrophication and climate change. Harmful Algae 2012, 14, 313-334. [CrossRef]

4. Michalak, A.M.; Anderson, E.J.; Beletsky, D.; Boland, S.; Bosch, N.S.; Bridgeman, T.B.; Chaffin, J.D.; Cho, K.; Confesor, R.; Daloglu, I.; et al. Record-setting algal bloom in lake erie caused by agricultural and meteorological trends consistent with expected future conditions. Proc. Natl. Acad. Sci. USA 2013, 110, 6448-6452. [CrossRef] [PubMed]

5. Dodds, W.K.; Bouska, W.W.; Eitzmann, J.L.; Pilger, T.J.; Pitts, K.L.; Riley, A.J.; Schloesser, J.T.; Thornbrugh, D.J. Eutrophication of U.S. Freshwaters: Analysis of potential economic damages. Environ. Sci. Technol. 2009, 43, 12-19. [CrossRef] [PubMed]

6. Le, C.; Zha, Y.; Li, Y.; Sun, D.; Lu, H.; Yin, B. Eutrophication of lake waters in china: Cost, causes, and control. Environ. Manag. 2010, 45, 662-668. [CrossRef] [PubMed]

7. Wentworth, J. Diffuse Pollution of Water by Agriculture; Houses of Parliament: London, UK, 2014.

8. Spears, B.M.; Carvalho, L.; Perkins, R.; Kirika, A.; Paterson, D.M. Long-term variation and regulation of internal phosphorus loading in loch leven. Hydrobiologia 2012, 681, 23-33. [CrossRef]

9. Spears, B.M.; Dudley, B.; Reitzel, K.; Rydin, E. Geo-engineering in lakes-a call for consensus. Environ. Sci. Technol. 2013, 47, 3953-3954. [CrossRef] [PubMed]

10. Bohutskyi, P.; Chow, S.; Ketter, B.; Fung Shek, C.; Yacar, D.; Tang, Y.; Zivojnovich, M.; Betenbaugh, M.J.; Bouwer, E.J. Phytoremediation of agriculture runoff by filamentous algae poly-culture for biomethane production, and nutrient recovery for secondary cultivation of lipid generating microalgae. Bioresour. Technol. 2016, 222, 294-308. [CrossRef] [PubMed]

11. Mata, T.M.; Martins, A.A.; Caetano, N.S. Microalgae for biodiesel production and other applications: A review. Renew. Sustain. Energy Rev. 2010, 14, 217-232. [CrossRef]

12. Srinivasan, A.; Viraraghavan, T. Dissolved air flotation in industrial wastewater treatment. In Water and Wastewater Treatment Technologies; Eolss Publishers: Oxford, UK, 2008.

13. Makuta, T.; Takemura, F. Simulation of micro gas bubble generation of uniform diameter in an ultrasonic field by a boundary element method. Phys. Fluids 2006, 18. [CrossRef]

14. Eddy, M.; Tchobanoglous, G.; Burton, F.; Stensel, H.D. Wastewater Engineering: Treatment and Reuse; McGraw-Hill Education: New York, NY, USA, 2002.

15. Zimmerman, W.B.; Tesar, V.; Butler, S.; Bandulasena, H. Microbubble generation. Recent Pat. Eng. 2008, 2, 1-8. [CrossRef]

16. Hanotu, J.; Bandulasena, H.C.H.; Zimmerman, W.B. Microflotation performance for algal separation. Biotechnol. Bioeng. 2011, 109, 1663-1673. [CrossRef] [PubMed]

17. Zimmerman, W.B.; Tesar, V.; Bandulasena, H.; Omotowa, O. Efficiency of an Aerator Driven by Fluidic Oscillation. Part ii: Pilot Scale Trials with Flexible Membrane Diffusers. Available online: http:/ / eyrie.shef. ac.uk/steelCO2/open/aerationefficiencypart2.pdf (accessed on 24 December 2017). 
18. Hanotu, J.; Karunakaran, E.; Bandulasena, H.; Biggs, C.; Zimmerman, W.B. Harvesting and dewatering yeast by microflotation. Biochem. Eng. J. 2014, 82, 174-182. [CrossRef]

19. Delgado-Baquerizo, M.; Maestre, F.T.; Reich, P.B.; Jeffries, T.C.; Gaitan, J.J.; Encinar, D.; Berdugo, M.; Campbell, C.D.; Singh, B.K. Microbial diversity drives multifunctionality in terrestrial ecosystems. Nat. Commun. 2016, 7, 10541. [CrossRef] [PubMed]

20. Stanley, M.; Jenkins, T. A UK Roadmap for Algal Technologies. NERC-TSB: 2013. Available online: http:/ / discovery.ucl.ac.uk/id/eprint/1462835 (accessed on 24 Decemebr 2017).

21. Wellburn, A.R. The spectral determination of chlorophyll-a and chlorophhyll-b, as well as total carotenoids, using various solvents with spectrophotometers of different resolution. J. Plant Physiol. 1994, 144, 307-313. [CrossRef]

22. Teeling, H.; Fuchs, B.M.; Becher, D.; Klockow, C.; Gardebrecht, A.; Bennke, C.M.; Kassabgy, M.; Huang, S.; Mann, A.J.; Waldmann, J.; et al. Substrate-controlled succession of marine bacterioplankton populations induced by a phytoplankton bloom. Science 2012, 336, 608-611. [CrossRef] [PubMed]

23. Brittle, S.; Desai, P.; Ng, W.C.; Dunbar, A.; Howell, R.; Tesar, V.; Zimmerman, W.B. Minimising microbubble size through oscillation frequency control. Chem. Eng. Res. Des. 2015, 104, 357-366. [CrossRef]

24. Mayers, J.J.; Flynn, K.J.; Shields, R.J. Rapid determination of bulk microalgal biochemical composition by fourier-transform infrared spectroscopy. Bioresour. Technol. 2013, 148, 215-220. [CrossRef] [PubMed]

25. Lourenco, S.O.; Barbarino, E.; Lavin, P.L.; Marque, U.M.L.; Aidar, E. Distribution of intracellular nitrogen in marine microalgae: Calculation of new nitrogen-to-protein conversion factors. Eur. J. Phycol. 2004, 39, 17-32. [CrossRef]

26. Murphy, J.; Riley, J.P. Citation-classic-A modified single solution method for the determination of phosphate in natural-waters. Anal. Chim. Acta 1962, 27, 31-36. [CrossRef]

27. Folch, J.; Lees, M.; Sloane-Stanley, G.H. A simple method for the isolation and purification of total lipids from animal tissues. J. Biol. Chem. 1957, 226, 497-509. [PubMed]

28. Vandenbrouck, T.; Jones, O.A.H.; Dom, N.; Griffin, J.L.; De Coen, W. Mixtures of similarly acting compounds in daphnia magna: From gene to metabolite and beyond. Environ. Int. 2010, 36, 254-268. [CrossRef] [PubMed]

29. Russo, D.A.; Couto, N.; Beckerman, A.P.; Pandhal, J. A metaproteomic analysis of the response of a freshwater microbial community under nutrient enrichment. Front. Microbiol. 2016, 7, 1172. [CrossRef] [PubMed]

30. Zhang, J.; Kobert, K.; Flouri, T.; Stamatakis, A. Pear: A fast and accurate illumina paired-end read merger. Bioinformatics 2014, 30, 614-620. [CrossRef] [PubMed]

31. Edgar, R.C. Search and clustering orders of magnitude faster than blast. Bioinformatics 2010, 26, $2460-2461$. [CrossRef] [PubMed]

32. Edgar, R.C.; Haas, B.J.; Clemente, J.C.; Quince, C.; Knight, R. Uchime improves sensitivity and speed of chimera detection. Bioinformatics 2011, 27, 2194-2200. [CrossRef] [PubMed]

33. Bokulich, N.; Rideout, J.; Kopylova, E.; Bolyen, E.; Patnode, J.; Ellett, Z.; McDonald, D.; Wolfe, B.; Maurice, C.; Dutton, R.; et al. A standardized, extensible framework for optimizing classification improves marker-gene taxonomic assignments. PeerJ PrePrints 2015, 3. [CrossRef]

34. Bao, E.; Jiang, T.; Kaloshian, I.; Girke, T. Seed: Efficient clustering of next-generation sequences. Bioinformatics 2011, 27, 2502-2509. [CrossRef] [PubMed]

35. Shannon, C.E. The mathematical theory of communication (reprinted). MDComputers 1997, 14, $306-317$.

36. Divakaran, R.; Pillai, V.N.S. Flocculation of algae using chitosan. J. Appl. Phycol. 2002, 14, 419-422. [CrossRef]

37. Gutzeit, G.; Lorch, D.; Weber, A.; Engels, M.; Neis, U. Bioflocculent algal-bacterial biomass improves low-cost wastewater treatment. Water Sci. Technol. 2005, 52, 9-18. [PubMed]

38. Chen, G.Y.; Zhao, L.; Qi, Y.; Cui, Y.L. Chitosan and its derivatives applied in harvesting microalgae for biodiesel production: An outlook. J. Nanomater. 2014, 2014, 217537. [CrossRef]

39. Henderson, R.; Chips, M.; Cornwell, N.; Hitchins, P.; Holden, B.; Hurley, S.; Parsons, S.A.; Wetherill, A.; Jefferson, B. Experiences of algae in uk waters: A treatment perspective. Water Environ. J. 2008, 22, 184-192. [CrossRef]

40. Chisti, Y. Biodiesel from microalgae. Biotechnol. Adv. 2007, 25, 294-306. [CrossRef] [PubMed]

41. Breuer, G.; Evers, W.A.C.; de Vree, J.H.; Kleinegris, D.M.M.; Martens, D.E.; Wijffels, R.H.; Lamers, P.P. Analysis of fatty acid content and composition in microalgae. J. Vis. Exp. 2013. [CrossRef] [PubMed] 
42. Gharami, K.; Das, M.; Das, S. Essential role of docosahexaenoic acid towards development of a smarter brain. Neurochem. Int. 2015, 89, 51-62. [CrossRef] [PubMed]

43. Letawe, C.; Boone, M.; Pierard, G.E. Digital image analysis of the effect of topically applied linoleic acid on acne microcomedones. Clin. Exp. Dermatol. 1998, 23, 56-58. [CrossRef] [PubMed]

44. Williams, H.C. Evening primrose oil for atopic dermatitis-Time to say goodnight. BMJ 2003, 327, 1358-1359. [CrossRef] [PubMed]

45. Cordell, D.; Drangert, J.O.; White, S. The story of phosphorus: Global food security and food for thought. Glob. Environ. Chaang. 2009, 19, 292-305. [CrossRef]

46. Sharpley, A.; Jarvie, H.P.; Buda, A.; May, L.; Spears, B.; Kleinman, P. Phosphorus legacy: Overcoming the effects of past management practices to mitigate future water quality impairment. J. Environ. Qual. 2013, 42, 1308-1326. [CrossRef] [PubMed]

47. Draaisma, R.B.; Wijffels, R.H.; Slegers, P.M.; Brentner, L.B.; Roy, A.; Barbosa, M.J. Food commodities from microalgae. Curr. Opin. Biotechnol. 2013, 24, 169-177. [CrossRef] [PubMed]

48. Krohn, B.J.; McNeff, C.V.; Yan, B.; Nowlan, D. Production of algae-based biodiesel using the continuous catalytic mcgyan ${ }^{\circledR}$ process. Bioresour. Technol. 2011, 102, 94-100. [CrossRef] [PubMed]

49. Smolinske, S.C. CRC Handbook of Food, Drug, and Cosmetic Excipients; Taylor \& Francis: Didcot, UK, 1992.

50. Becker, E.W. Microalgae in human and animal nutrition. Biotechnol. Adv. 2007, 25. [CrossRef]

51. Paerl, H.W.; Dyble, J.; Moisander, P.H.; Noble, R.T.; Piehler, M.F.; Pinckney, J.L.; Steppe, T.F.; Twomey, L.; Valdes, L.M. Microbial indicators of aquatic ecosystem change: Current applications to eutrophication studies. FEMS Microbiol. Ecol. 2003, 46, 233-246. [CrossRef]

52. Qin, B.Q.; Gao, G.; Zhu, G.W.; Zhang, Y.L.; Song, Y.Z.; Tang, X.M.; Xu, H.; Deng, J.M. Lake eutrophication and its ecosystem response. Chin. Sci. Bull. 2013, 58, 961-970. [CrossRef]

53. Pan, G.; Chen, J.; Anderson, D.M. Modified local sands for the mitigation of harmful algal blooms. Harmful Algae 2011, 10, 381-387. [CrossRef] [PubMed]

(C) 2017 by the authors. Licensee MDPI, Basel, Switzerland. This article is an open access article distributed under the terms and conditions of the Creative Commons Attribution (CC BY) license (http:/ / creativecommons.org/licenses/by/4.0/). 